\title{
The changing of the guard
}

\author{
Thomas L. Slovis
}

Received: 18 October 2012 / Accepted: 18 October 2012 / Published online: 26 October 2012

(C) Springer-Verlag Berlin Heidelberg 2012

It has been my privilege to serve as assistant editor and editor of your journal for the last 18 years. We have focused on helping our readership improve health care in children by presenting a diverse array of manuscripts, minisymposia and supplements that cover vital and, at times, controversial material (ALARA and child abuse to name two). In editorials and commentaries, we have prodded you to be more involved in patient care and consultative services [1-4]. We advocate for children! We have tried to be inclusive, working with our interventional colleagues to use the journal as their own and having nonimaging pediatric health care providers as reviewers and authors.

With Steve Chapman and Guy Sebag, we have made this one journal, as opposed to an American (North American) and a European (rest of the world) edition. We have strived to overcome geographical prejudices and take a global view of improving children's health care. I have used the term "we" many times in this editorial, because the "we" has made this a most gratifying experience. I have had four of the best assistant editors-Don Frush, Brian Coley, Peter Strouse, Cynthia Rigsby - whose expertise and dedication and above all friendship I will always treasure. All of us know that despite how hard we work, the person who really "makes the journal" is the assistant to the editor, Pat Vario. Pat has helped the publishers, authors and readers get through innumerable problems. She really is everyone's "best friend." I am indebted to Pat and cannot ever thank her enough.
I believe that we communicate best not by email, but on the phone or, whenever possible, face to face. My goal was to make every author better-even if the article was rejected, the author should learn how to improve the paper for future submissions.

As my term as editor comes to a close, I want to emphasize that, although the editorial team can set the tone, the journal is never better than its authors, reviewers and editorial board. I thank all of you who have become involved in Pediatric Radiology and, through your involvement, made it richer.

I congratulate Peter Strouse on his selection as Editor of the Americas. It is well deserved. I urge the continuing advocacy and involvement of the journal in improving children's health and will always be involved at whatever level the editors deem fit.

\section{References}

1. Slovis TL (2012) Ownership. Pediatr Radiol 42:2297

2. Slovis TL (2007) The easier path-a blueprint for failure. Pediatr Radiol 37:415-416

3. Slovis TL (2007) The path less travelled - a road to success. Pediatr Radiol 513-514

4. Slovis TL (2000) The Society for Pediatric Radiology Presidential Address: the future of pediatric radiology in children's hospitals. Pediatr Radiol 30:878-880

\footnotetext{
T. L. Slovis $(\bowtie)$

Department of Pediatric Imaging, Children's Hospital of Michigan,

Wayne State University School of Medicine,

3901 Beaubien Blvd.,

Detroit, MI 48201, USA

e-mail: tslovis@med.wayne.edu
} 